\title{
Construções do Feminino Pós Anos Sessenta: O Caso da Maternidade como Produção Independente
}

\author{
Ana Maria Szapiro ${ }^{123}$ \\ Universidade Federal do Rio de Janeiro \\ Terezinha Féres-Carneiro \\ Pontificia Universidade Católica do Rio de Janeiro
}

\begin{abstract}
Resumo
Este trabalho examina a representação do feminino nos discrusos sobre a maternidade através de entrevistas feitas em um grupo de cinco mulheres pertencentes aos extratos médios urbanos e que relataram ter tido seus filhos como "produção independente". As entrevistadas eram profissionais de nível superior, entre quarenta e cinqüenta anos de idade, tiveram seus filhos na década de oitenta, e viveram, como experiência geracional, as discussões de cunho libertário e feminista dos anos sessenta. Os resultados mostraram que as entrevistadas partilham de um mesmo ethos, apresentando os mesmos valores e crenças quanto à independência e à liberdade, e quanto ao lugar tradicionalmente destinado à mulher na maternidade. A "produção independente" revelou-se uma tentativa de construção de um novo lugar para a mulher, a partir do reconhecimento da maternidade como questão feminina, submetida, entretanto, ao universo dos valores do individualismo moderno.
\end{abstract}

Palavras-chave: Feminino; "produção independente"; individualismo; desejo de filho; procriação.

Feminine Constructions after The Sixties: The Issue of Optional Single Motherhood

Abstract

This article examined the feminine representation through the speeches of five middle class, urban women about motherhood. All the subjects interviewed were between forty and fifty years old, were professionals, had university degrees and reported having had their children as single mothers in the eighties. Their generation experienced the discussions of liberation and feminism of the sixties. The results showed that the subjects shared the same ethos and presented similar values and belief concerning independence, freedom and the place traditionally assigned to women as mothers. The option to become a single mother appeared as an attempt to build a new place for women, starting from the acknowledge of motherhood as a feminine issue subjected, however, to the universe of modern individualism values.

Keywords: Feminine; "optional single motherhood"; individualism; desire to have a child; procreation.

Este artigo analisa a problemática da "produção independente", experiência de maternidade que surgiu com esta denominação nos anos sessenta e setenta no Brasil. Para este efeito entrevistamos mulheres que assim denominaram sua experiência de mães, procurando analisar, através dos seus discursos, alguns aspectos que dizem respeito às construções do feminino, como destacamos no título.

Consideramos, portanto, a "produção independente" na perspectiva de uma construção, um acontecimento, dentre outros, que se inscreve no interior das mudanças subjetivas em curso nas sociedades ocidentais modernas, particularmente as que surgiram a partir da segunda

${ }^{1}$ Endereço para correspondência: Rua Gustavo Sampaio, 710/202, Rio de Janeiro, RJ, 22010-010. Fone/Fax: (21) 22751469. E-mail aszapiro@pcshop.com.br

Parte do trabalho de Tese de Doutorado da primeira autora (bolsista da CAPES) sob orientação da segunda autora.

Agradecimentos a Profa. Circe Navarro Vital Brazil, in memorian; ao Prof. Joel Birman; e às entrevistadas. metade do século XX. Estas mudanças têm produzido uma inflexão profunda nos valores ligados à idéia de liberdade e de autonomia dos indivíduos.

Dentre as mais recentes e importantes transformações nas mentalidades da sociedade moderna, que vêm colocando em questão alguns valores axiais e constitutivos do indivíduo, devemos destacar a defesa intransigente da igualdade entre homens e mulheres, as mudanças referentes aos problemas de filiação (mais acentuadamente com a introdução das novas tecnologias de reprodução - NTR) e, por final, a minimização do valor atribuído à ancestralidade. A respeito do valor da ancestralidade, Hobsbawm (1994) comenta que: "a destruição do passado - ou melhor, dos mecanismos sociais que vinculam nossa experiência pessoal à das gerações passadas - é um dos fenômenos mas característicos e lúgubres do final do século XX”' (p. 13).

Tomamos, neste trabalho, como principais referências teóricas, a teoria de Dumont quando trata da ideologia individualista moderna e a teoria freudiana quando pensa sobre a problemática do sujeito moderno, da questão 
simbólica da filiação e da ancestralidade. A “produção independente" demanda analisar as implicações de um complexo trabalho de construção. Sendo complexo, devemos levar em conta não só as dimensões que são peculiares a cada época em que se produzem, mas também aquelas que dizem respeito às singularidades de interpretações feitas por cada indivíduo. Nossos dilemas são próprios à época em que vivemos mas, ao mesmo tempo, não podem ser reduzidos a explicações que não levem em conta tais singularidades que escapam à razão e que, por sua vez, nos apontam o inesperado e o criativo de cada um de nós, como nos propõe a perspectiva contida na tese freudiana sobre a natureza da relação entre o homem e a cultura (Freud, 1930).

“Produção Independente": Os Limites da Igualdade Com relação à discussão sobre a igualdade entre homens e mulheres, atravessamos todo o século questionando os princípios da divisão sexual nos espaços do público e, depois no privado. A crescente feminização da sociedade moderna ao longo de todo o século não eliminou, contudo, formas, nem sempre sutis, de segregação da mulher no mundo do trabalho, formas que permanecem até os nossos dias.

Os primeiros discursos de lutas das mulheres pela melhoria de condições de trabalho, já desde o século dezenove, sinalizavam que o debate sobre a relação homem-mulher estava definitivamente colocado na agenda de discussões sobre as desigualdades sociais. No Brasil, as primeiras lutas trabalhistas e sufragistas das mulheres datam do final do século dezenove e das primeiras décadas do século vinte, e, ainda que restritas às questões do trabalho, introduziram na sociedade brasileira o debate sobre a desigualdade na relação homem-mulher e sobre a opressão dos homens sobre as mulheres. As lutas das mulheres inscreviam-se no interior das lutas das minorias em geral, apoiando-se na crença da existência de um indivíduo racional universal.

A descrição biológica moderna da diferença sexual do século XVIII pôde superar a teoria hierárquica do modelo de um só sexo (Laqueur, 1990) que sustentava idéia de uma inferioridade da mulher. Tomando como referência o corpo do homem, o modelo de um só sexo descrevia o corpo da mulher como um corpo imperfeito portanto, inferior. A moderna teoria biológica sobre a diferença sexual, vem afirmar uma concepção universalizante do ser humano, possuidor de uma natureza igual que nos faria pertencermos igualmente à sociedade dos humanos. A natureza deixou de ser compreendida através de paradigmas religiosos, e passou a pertencer à ciência conformando-se em objeto de conhecimento a ser desvendado pela razão humana.
Iguais na natureza, possuindo, portanto, iguais direitos políticos e jurídicos e, ao mesmo tempo diferentes, porque biologicamente diferentes, homens e mulheres poderiam formar parte da moderna sociedade de contrato, como indivíduos, como cidadãos. Se a ancoragem no paradigma biológico pôde sustentar, a partir do século XVIII, as razões da diferença, persistiu, entretanto, a oposição entre o discurso igualitário, fundado na natureza universal do indivíduo, e a interpretação social da diferença anatômica, que continuou a colocar a mulher em um lugar social inferior ao homem. Os novos corpos, ordenados não mais hierarquicamente, permaneceram ocupando lugares sociais diferentes, justificados pela singularidade da posição da mulher na procriação.

O novo modelo biológico, como ressalta Bourdieu (1990), ao deslocar as representações do modelo de um só sexo para um discurso racional, científico e, portanto, conforme aos ideais universalizantes, fez permanecer a marca cultural da representação de uma certa imperfeição da mulher presente no modelo anterior, através da reafirmação da virilidade como fator diferencial. Subsistiu no novo sistema representacional dos corpos a antiga imagem da especificidade da mulher: ela, e só ela, pode dar a vida.

Interpretada como obstáculo à igualdade, a maternidade, enquanto diferença irredutível, foi colocada no centro das discussões nas diversas correntes do movimento feminista, num debate que atravessou toda a segunda metade do século XX. A partir dos anos sessenta encontramos nos discursos de importantes representantes do movimento feminista a proposição de que a maternidade seria uma condição da qual toda mulher deveria tentar escapar. Isto porque seria exatamente nesta condição que a mulher seria submetida a uma maior opressão por parte do homem. Escapar da maternidade também significava, para a mulher, não mais aceitá-la como um destino inevitável e sim concebê-la como uma escolha livre e autônoma, como uma opção

É neste cenário que surgiu a "produção independente". Esta maternidade surge, a nosso ver, como uma problemática específica à discussão sobre a desigualdade entre homem e mulher não apenas no que se refere ao vínculo contratual da sociedade, mas também nos seus reflexos sobre a desigualdade nos espaços privados das relações que se articulam em novas concepções sobre família e sistema de filiação.

\section{Maternidade: Uma Questão Biológica?}

Em estudos que abordam a problemática da maternidade, encontramos, com certa freqüência, uma tendência a biologizar a questão, tratando-a como uma 
questão de reprodução humana, o que tem resultado em des-subjetivá-la, e reduzi-la ao fato biológico. Esta não é a abordagem deste trabalho. Queremos retomar a maternidade na sua irredutibilidade simbólica, irredutibilidade que encerra o sentido da procriação humana.

A "produção independente" nos conduz, também, a pensar na questão da monoparentalidade que, por sua vez, constitui um dispositivo de análise importante para compreensão das novas formas de transmissão geracional que daí podem emergir. Reafirmando a separação entre sexualidade e reprodução, a "produção independente" dos anos sessenta e setenta pode ser interpretada como uma ante-sala das novas tecnologias de reprodução, mas indica, sobretudo, como pudemos constatar através dos discursos das entrevistadas, um momento de questionamento quanto ao lugar da mulher na sociedade moderna. Este questionamento é conseqüência da adesão ao projeto individualista moderno, da crescente presença das mulheres no mundo público- até os primeiros anos do século XX, um território masculino - e dos progressos da ciência biológica no campo da reprodução humana.

Os recursos contraceptivos que surgiram nos anos sessenta - a pílula anticoncepcional, em particular - se, por um lado, vieram atender à demanda crescente de liberdade da mulher, por outro mobizaram também todo um campo desejante, ligado à procriação, seja no homem, seja na mulher. Para Tort (1995), o controle da concepção, quando se torna possível cientificamente, modifica as condições inconscientes de emergência do desejo de filho.

\section{Individualismo, Feminismo e Feminino}

D: "Eu disse: não estou ligando pra te pedir nada... eu só estou te informando, porque isto é um direito que você tem... eu nunca vou te procurar... agora não estou fechando nenhuma porta, a hora que você quiser conbecê-la... eu acho que é um direito que você tem... Ele nunca procurou..."

A questão do individualismo enquanto ideologia organizadora das sociedades ocidentais modernas, foi exaustivamente analisada por Dumont (1993), que sublinha nestas sociedades a maximização do valor da "igualdade" enquanto valor intrínseco à categoria de indivíduo. Ao contrário, as sociedades tradicionais organizam-se segundo um princípio hierárquico, em cuja configuração ideológica não se faz presente a idéia de igualdade entre seus indivíduos. Estes ocupam diferentes lugares sociais, harmônicos a uma ordem cósmica que os transcende, e é esta ordem, preexistente aos indivíduos, que regula e dá sentido ao todo social. As diferenças são, portanto, de natureza, decorrentes do princípio organizador.

Psicologia: Reflexão e Crítica, 2002, 15(1), pp. 179-188
Quanto 'as sociedades modernas, não só a idéia de igualdade mas também a idéia de progresso, de desenvolvimento, apresenta o indivíduo como projeto, aberto a infinitas possibilidades. A divisão entre o que é permitido e o que é proibido, desliza, na modernidade, para outra divisão, aquela entre o possível e o impossível, onde o impossível hoje poderá ser amanhã possível (Ehrenberg, 1998). Este deslizamento fala a favor de um imaginário onde o homem acredita poder-se construir por si mesmo, para além dos constrangimentos sociais, não mais determinado pelo passado, mas indeterminado pelo futuro.

A crença na liberdade de escolha como valor, como formadora da idéia de indivíduo é o indicador de verdade do imaginário moderno. $\mathrm{Na}$ construção deste projeto, qualquer constrangimento ao exercício desta liberdade é geralmente vivido com sofrimento. Toda restrição colocada pelo outro social é repudiada em nome da liberdade de escolha.

A constituição do sujeito, tal como formulada por Freud, é tributária da noção de intersubjetividade. Mas, no imaginário libertário, começa a prevalecer o que Sennett (1980) apontou como potencialização de um estado de mobilização narcísica.

Assim, a idéia da liberdade de escolha, ao estabelecer a crença na autonomia do indivíduo, colocou em questão valores ligados às relações inter-geracionais. Porque, ao considerar-se independente e autônomo, relativamente às injunções sociais, o indivíduo moderno desenraíza-se das referências de filiação, e, reconhecendo-se a si mesmo como portador de direitos, constrói-se subjetivamente como senhor absoluto de seus projetos, num lugar de anterioridade frente ao outro social.

Isto se faz ao preço da sua constituição intersubjetiva. O que se observa na questão da maternidade como "produção independente", é que a emergência do desejo de filho parece negar o caráter relacional da maternidade - (todo filho é filho de dois...), possivelmente pelo malestar constante que ameaça o indivíduo moderno ao ter que constranger-se face ao outro, na dualidade construída pela oposição indivíduo versus sociedade.

Projeto, e não destino (Velho, 1988), a maternidade moderna passa a ser uma questão de livre arbítrio, apoiada na liberdade que a ciência ofereceu à mulher. E, como projeto, a maternidade é do indivíduo, antes de ser do par..

\section{Feminismo e Projeto Individualista}

Dentre as diferentes correntes de pensamento que conformaram o movimento feminista dos anos sessenta e setenta uma delas, bastante forte e influente, atribuía ao 
casamento e à maternidade a causa da opressão das mulheres pelos homens. Beauvoir (1980) dizia que a maternidade favorecia o exercício da dominação masculina Trinta anos depois da publicação de sua obra, o Segundo Sexo, em entrevista a Schwarzer (1985) ela sugere que: ... "se a mulher quiser ter filhos, ...é melhor que os tenha sem casar, porque o casamento é a maior armadilha" (p.72).

As lutas das mulheres no final do século dezenove reivindicando mecanismos de proteção relativos necessidades de regulamentação das suas condições de trabalho na Inglaterra e nos EEUU, defendendo direitos de liberdade para escravos, ou ainda discutindo o direito ao voto, as conhecidas lutas de cunho sufragista, foram todas lutas de cunho libertário. A adesão ao projeto igualitário foi se impondo, ao mesmo tempo que, com o avanço do capitalismo industrial, constituiu-se mais definitivamente a divisão de valores entre dois mundos: o mundo da produção e o mundo da esfera doméstica privada. As mulheres, embora de modo desigual em relação aos homens, estavam incluídas simultaneamente nas duas esferas.

No mundo da produção, as mulheres passaram a lutar por leis e direitos iguais aos dos homens. Perceberam-se enquanto indivíduos inseridos no mundo da produção, num mundo marcado, entretanto, pela desigualdade entre homens e mulheres. Os discursos próprios dessas lutas constituíram o movimento de mulheres do século XX, acentuando-se, sobremodo, nos anos sessenta com o questionamento da desigualdade entre homens e mulheres nas esferas pública e privada. Estes foram anos de intensas discussões em torno das questões ligadas à liberdade. A idéia de que haveria uma sociedade sem repressão, sociedade onde os indivíduos poderiam ser felizes, a idéia portanto, de que a causa da infelicidade humana estava no caráter repressor da sociedade, foi a tônica dos discursos dos movimentos da época. Liberdade identifica-se com felicidade.

Observaram-se, então, mudanças quanto às expectativas de relacionamentos amorosos, casamento, família, em resumo, com relação à esfera mais íntima. Livrar-se da repressões sociais e voltar-se para a realização de seus próprios projetos, para suas próprias exigências de prazer de auto-realização constituiu um novo campo de conflito subjetivo marcado por acentuada inflexão narcísica.

As margens de negociação nas relações entre o indivíduo e o outro diminuíram enormemente. Frente à maximização do valor da liberdade individual, a idéia de renúncia, possibilidade sempre presente no desenrolar das trocas afetivas, tornou-se fonte de questionamentos e até mesmo causa de ruptura das relações. Se no universo da Antigüidade grega, a renúncia se revestia de um caráter eminentemente social, uma prova de entrega e exercício para a boa fortuna individual, na modernidade, na supremacia da liberdade, a prova de amor não é dirigida ao outro, mas a si mesmo!

Nas transformações da família, o valor de liberdade também acentuou traços narcísicos. Na problemática da procriação, o imaginário libertário dos anos sessenta produziu um discurso de repúdio a qualquer forma de dominação masculina sobre as mulheres, situação atribuída à maternidade que, portanto, as mulheres deveriam evitar.

Assim, a mulher, para ser igual ao homem, deveria negar-se à experiência que, na natureza, ou seja, no biológico, e no sentido mesmo do imaginário da cultura, designa o lugar específico da mulher. $\mathrm{Na}$ emergência de um novo lugar para a mulher, a maternidade passou a ser incluída não mais como destino inevitável, mas como um projeto a ser ou não realizado.

Com o advento da pílula anticoncepcional, a ciência ofereceu à mulher a liberdade de ter filhos quando ou se quisesse. Ficar grávida, antes da descoberta dos métodos contraceptivos, particularmente da pílula, era um acontecimento, na maior parte das vezes inesperado, não controlado pela mulher. Cabia ao homem, em última instância, a decisão. A gravidez da mulher passava, portanto, pelo desejo do homem. A gravidez era uma possibilidade do ato sexual, a sexualidade estava vinculada diretamente à procriação.

Com a pílula esta situação se inverteu. Os contraceptivos (a pílula, em especial), contribuíram para a autonomização do desejo das mulheres com relação ao desejo dos homens. Quando a maternidade pôde ser objeto de planejamento, o ato sexual pôde passar a representar tão somente uma experiência de prazer, desvinculando-se da questão da procriação. A pílula, como recurso contraceptivo, transformou a maternidade em uma opção planejada e talvez tenha sido, num certo sentido, o maior aliado do discurso feminista. A prática da contracepção fez surgir um tipo de esterilidade voluntária.

T: "Ai en tentei o diafragma, só que achei que aquilo ia ser horroroso, botei o DIU, depois tirei. Eu tinha pedido para o men médico ligar minhas trompas um mês ou dois meses antes da gravidez. acontecer, e ele falou: mas eu não vou fazer isto e eu disse: não está nos meus planos ter filhos, en não vou querer ter filhos, pelo amor de Deus!..."

A representação da maternidade como um projeto (e não como destino) contribuiu para maior penetração dos valores individualistas no interior da família, na medida em que passou a ser compreendida como uma decisão racionalizada, planejada segundo as circunstâncias. Entretanto, vale ressaltar, como faz Duarte (1995), que a maternidade, ainda assim, continua a ser "uma 'tarefa', 
objeto da partilha familiar, que resiste à equalização ou equiparação individualizante, apesar de todos os avanços biomédicos e tecnológicos disponíveis" (p.36). O autor se refere aqui a um constrangimento biológico próprio que, apesar das transformações nos modos de pensar, permanece e traz um ponto de tensão no interior da família moderna, tensão entre um imaginário de relações igualitárias individualizantes e uma subjetividade hierarquizada pela impossibilidade de repartição de algumas tarefas próprias à maternidade, apesar das formulações e experiências muito em voga nos anos setenta como o surgimento do casal grávido (Salém, 1985).

Apesar de não analisar a questão nos termos propostos por Dumont (1993) quanto aos efeitos da ideologia individualista, Bourdieu (1990), discutindo o problema da dominação masculina como uma forma de violência simbólica, chama atenção para o fato de que alguns argumentos em defesa da igualdade frente aos homens, contidos nos discursos feministas, reproduzem categorias próprias à lógica de dominação masculina. $\mathrm{O}$ autor ressalta que estes argumentos mostram estruturas conscientes e inconscientes, construídas em conformidade com o modo de estruturação presente na relação de dominação masculina que é imposta às mulheres.

\section{Procriação ou Reprodução?}

Do ponto de vista da cultura há, como já mencionamos acima, uma identificação entre as representações de mulher e de mãe, identificação pela qual ser mãe seria o destino natural a todas as mulheres. Não nos esqueçamos que a mulher perfeita no Antigo Testamento é fecunda, mãe e dedicada à casa.

As sociedades modernas obedecem a um sistema de transmissão patronímico, o que determina a atribuição do nome do pai ao filho. Como argumenta Héritier (1996), todas as sociedades humanas fundam suas regras de filiação - quaisquer que sejam estas regras - sobre suas interpretações do fato biológico. Ou seja, do ponto de vista da cultura humana, não existe fato biológico em si, o que existe são, portanto, discursos próprios a cada cultura que constituem os fatos biológicos.

As recentes descobertas no campo da Biologia da reprodução, têm determinado, crescentemente, uma hegemonia do discurso biológico sobre a procriação, que passa a ser tratada, cada vez mais, nos dias atuais, como uma questão de reprodução humana. Esta hegemonia é tributária, a nosso ver, da idéia tão cara à crença moderna de que a realidade se constitui (e se reduz também ...) apenas ao que pode ser explicado através do paradigma racional científico. Assim vemos, que nos dias atuais, ter um filho pode não passar necessariamente pelo encontro entre um Psicologia: Reflexão e Crítica, 2002, 15(1), pp. 179-188 homem e uma mulher com toda a complexidade que advém deste encontro. No paradigma estritamente biológico, homem e mulher tornam-se apenas geradores de um embrião... A partir deste paradigma, transformações importantes nos sistemas de filiação já começam a ocorrer hoje.

De qualquer maneira, é importante pensarmos que, em qualquer circunstância humana, em se tratando da cultura, uma questão se impõe: apenas a transmissão de um patrimônio simbólico permite às novas gerações se situarem num sistema de filiação, encontrando, portanto, um lugar no grupo ancestral de referência, grupo que funciona como suporte fundador das identidades, como porta de entrada única para a constituição de um sujeito da cultura. O patrimônio simbólico é o que autoriza a nova geração a deter direitos simbólicos de pertencimento ao seu grupo, e a estabelecer, desta forma, a sua identidade cultural. Por outro lado, pertencer ao grupo implica na sujeição às interdições de uma dada cultura, condição que faz instar cada ser humano à produção dos sentidos singulares e mesmo a tentativas de contornar, ainda que sempre de modo insatisfatório, tais interdições.

O que acontece quando o sistema de filiação é reduzido ao fato biológico é que se apaga, por assim dizer, o lugar da ancestralidade. $\mathrm{Na}$ verdade, como o submetimento às regras da cultura que dizem respeito à herança simbólica determina constrangimentos, imposições, exclusões e inclusões que o indivíduo "libertário" não quer aceitar, a biologização da procriação funciona como uma tentativa de escapar aos limites simbólicos colocados pela cultura.

Numa análise sobre os novos modos de procriação, ainda Héritier (1996) sustenta que não existe nenhuma sociedade humana que tenha sido fundada sob a consideração única da reprodução biológica, ou que tenha reconhecido a esta o mesmo valor que o da filiação socialmente definida. Todas as sociedades, ao fundarem suas regras de filiação sobre a interpretação do fato biológico, constituem uma idéia socialmente aceita sobre a diferença sexual, o que quer que isto signifique para cada uma delas. A menos que estejamos falando de reprodução assexuada - onde seria impossível pensar a diferença, pois tratar-se-ia da reprodução do mesmo o campo de possibilidades das regras de filiação pode variar, mas não é infinito.

Abrem-se, assim, duas vias de compreensão (que nos auxiliarão na análise dos discursos das entrevistadas) para a questão da procriação: uma referida ao ponto de vista antropológico sobre o indivíduo, outra ao ponto de vista da teoria freudiana sobre o sujeito.

Se seguimos a leitura de Dumont (1993), como a ideologia individualista foi, passo a passo, desancorando 
o indivíduo da sua própria história, o passado passou a trazer uma forma de dominação, de mal-estar e de constrangimento. Trazendo a história vivida por cada um, o passado relança o indivíduo num mundo marcado pelas histórias que o antecederam (seus antepassados), que constituem sua dimensão de transcendência, seus determinantes intersubjetivos.

Aqui, encontramos a tese freudiana segundo a qual o sujeito se funda na cultura, numa alteridade, se constitui a partir de um outro. Para Freud, as primeiras marcas psíquicas do sujeito humano surgem a partir da experiência de um corpo, porque o eu é, antes de tudo, eu corporal, é um precipitado de identificações que dão prova da inegável presença de um outro como fundamento. Vale lembra Birman (1997) quando argumenta que, nos termos formulados por Freud, o sujeito nunca é causa de si mesmo!

\section{Método}

\section{Participantes}

Participaram como sujeitos da pesquisa cinco mulheres pertencentes a extratos médios urbanos que diziam te escolhido ser mães, apesar ou independente da aceitação do parceiro, e que se referiam a si mesmas como mães de "produção independente". Outro critério que norteou a escolha das entrevistadas foi o de sua localização em termos de experiência geracional, já que estávamos interessadas em investigar a problemática desta experiência de maternidade, que surgiu a partir dos discursos libertários e feministas dos anos sessenta e setenta. Todas as entrevistadas tiveram seus filhos na década de oitenta, e suas histórias de vida situam suas experiências de juventude nestes anos. As mulheres que participaram deste estudo são todas profissionais de nível superior. Elas tinham, à época das entrevistas, entre quarenta e cinqüenta anos e vieram todas de cidades pequenas, seja do interior do Estado do Rio de Janeiro ou do interior de outros estados do Brasil.

\section{Procedimentos}

As entrevistadas foram indicadas por pessoas com as quais a entrevistadora (a primeira autora deste artigo) mantinha algum tipo de relação profissional. Todas as entrevistadas tomaram conhecimento do objetivo desta investigação e não apresentaram qualquer restrição à sua participação, pelo contrário, ofereceram seus depoimentos com absoluto empenho e boa vontade.

As entrevistas foram realizadas nos anos de 1997 e 1998. Com exceção de uma delas, todas as pessoas foram entrevistadas duas e, em alguns casos, três vezes. Todas as entrevistas foram realizadas nas residências das entrevistadas, foram gravadas com a aprovação das mesmas e posteriormente transcritas. Estas entrevistas, bastante longas, se constituíam em narrativas de experiências, onde as pessoas contavam suas histórias de vida, remetendo sempre a experiências de infância e analisavam seus relacionamentos com suas famílias de origem. Havia um pequeno roteiro inicial que serviu apenas como referência para, caso necessário, tentar abordar algum aspecto importante que, eventualmente, não tivesse sido abordado durante a entrevista.

Interações verbais freqüentes entre entrevistadora e entrevistadas também contribuíram para coletar dados mais amplos e significativamente relevantes, relativos aos diferentes e específicos contextos culturais das entrevistadas.

A partir das histórias de vida foram selecionadas para análise as seguintes dimensões dos discursos:

a) desejo de filho

b) masculino e feminino, ou seja, as representações de feminino e masculino trazidas pelas entrevistadas. A questão que se colocou foi: como estas mulheres representavam para si a questão da diferença de gêneros?

c) a conjugalidade possível: nesta dimensão analisamos as representações construídas a respeito do casamento e das relações amorosas, ainda considerando os efeitos da ideologia individualista e do discurso feminista.

Procuramos analisar, através destas dimensões, os valores presentes nos discursos que, a nosso ver, tornaram possível a emergência da experiência de maternidade de "produção independente".

A opção metodológica foi feita considerando os objetivos do estudo de procurar apreender, nas formas de descrever e analisar as experiências, as preocupações e perplexidades presentes nos discursos, compreendidos como produções subjetivas nas suas dimensões históricoideológicas. Ou seja, procurou-se indagar sobre esta experiência de maternidade, colocando a "produção independente" como um acontecimento produzido socialmente.

\section{Resultados e Discussão}

Os Discursos sobre a "Produção Independente"

O material mostra que as entrevistadas partilhavam de um mesmo ethos, apresentando, claramente, as mesmas crenças, os mesmos valores e concepções quanto à independência, à liberdade e mesmo quanto às representações de maternidade e de mulher. Com relação à questão da decisão de ter o filho, independentemente do desejo do parceiro, gostaríamos de ressaltar dois principais aspectos. O primeiro aspecto (e que foi objeto de uma das dimensões da análise) está no discurso sobre a decisão de ter o filho. 
Este discurso sobre o filho que se decidiu ter, sustenta-se na idéia de que ter um filho é uma decisão racional.

N: "Na realidade, eu achava que... Sempre achei, e isso faz.parte da nossa geração... De pessoas que foram militantes e que tiveram.. Que a gente achava que era complicado botar um filho no mundo, com os valores que existiam na época...e tudo"

T: "E aos 36 anos o médico chegon e falou que eu não podia mais tomarpilula, en falei: olha eu acho que eu sou uma coelha, tenho que fazer alguma coisa pra evitar..."

$\mathrm{N}$ : "Eu acho que a criança "pintou" pra mim na hora certa. $\mathrm{Na}$ bora que não causou nenbum problema eu ficar em casa por causa do filho, entende? O filho "pintou" na bora certa, na hora que eu tinha maturidade para ter filho. Antes eu não tinha..."

Esta crença na idéia da maternidade como decisão racional ou opção, produziu como efeito na subjetividade, o recalcamento da dimensão simbólica da procriação, em favor de explicações biológicas que asseguram nos discursos a certeza de que o fato da gravidez é algo perfeitamente racional. Se o filho "pintou" - e aqui o discurso deixa escapar o desejo, o que poderia significar um não controle - , N. logo acrescenta que "pintou" na hora certa, quando ela já tinha maturidade. Tudo volta, assim, a estar sob controle, e, por isto foi possível decidir ter o filho. Por outro lado, $\mathrm{N}$ diz que a gravidez não causou nenhum problema, ela podia ficar em casa, ou seja, a gravidez não é afirmada diretamente em sua positividade, mas é sustentada através do argumento de que, naquele momento, não causaria nenhum problema. Talvez por ser o testemunho irrefutável da diferença e da especificidade da mulher, na afirmação da igualdade o desejo de filho não pode ser diretamente formulado.

F: "...eu acho que na maioria das relações a mulher é muito oprimida... Até porque a mulher não tem visão do poder dela. Essa coisa do homem é milenar, o homem grita, o homem manda." F: "...Eu acho que tem a coisa do papel da mulher ter se realizado, essa coisa de ter desenvolvido a função, aquela coisa, eu tenho útero, en posso procriar..(...) Minha mãe era diferente

de todas as mães, era totalmente diferente, minha mãe fazia vestidos lindos pra gente, e minha festa de quinze anos foi uma coisa de sonbo que ela fez... Tudo ela fazia, todas as determinacões da casa eram dela...men pai era uma pessoa que só trabalhava e ela resolvia a fantasia da gente... Quem faz isso, quem tem que sentir, então é quem está mais próximo da criança..."

$\mathrm{T}$ : "Ser mãe é que é a natureza feminina. Porque o resto, tudo a gente pode fazer. Existem certas coisas que eu acho da natureza feminina, que nós somos mais... é biológico, provado biologicamente. Nosso cérebro é o medo do homem. O cérebro masculino é dividido, o da mulher é unido. Dai eu acho que a nossa coisa do racional e emocional tá meio equilibrado, mistura um pouco...enquanto o homem tem uma visão racional de uma coisa, emocional de outra. Daí, às vezeses, até assim, as tendências masculinas, femininas e tal, de sensibilidade, que eu acho que a mulher é mais sensivel do que o homem até por causa disso, que nós temos a coisa unida... eu acho que existe uma questão biológica..."

O mesmo dispositivo de saber legitimou, biologicamente, a diferença sexual e, como dissemos, reconstruiu uma nova hierarquia natural entre os sexos. Esta certeza científica sobre os processos de reprodução e, mais do que isto, o grau de intervenção possível sobre estes processos determinou mudanças importantes. A idéia do filho programado, a questão da decisão sobre a interrupção de uma gravidez que não se quer porque ainda não é o momento, a discussão sobre as condições ideais a partir das quais podese desejar um filho, são questões absolutamente novas, que surgiram a partir desse imaginário de controle das tecnologias contraceptivas:

T: "Eu trabalhava... Então nessa época eu falei: não, não dá pra ter filho, né?"

Entretanto, neste imaginário de liberdade de opção, regulado biologicamente, o desejo de filho como manifestação inconsciente se impôs, resultando para T em um acontecimento (a gravidez improvável) que foi inesperado, por oposição a um querer sempre planejado: T: "E ai eu passei a tomar pilula a minha vida inteira, teve o meu segundo relacionamento, eu tive uma gravidez...Porque eu, sabe aquela coisa esqueci de tomar hoje, vou tomar às duas horas da manhã, e nessa, mas sabe? Eu não senti segurança para assumir... não era pra ser, não tinha que ser... e fiz. um aborto... aquilo tudo foi muito doído para mim, até porque en tive uma hemorragia e eu cheguei para o médico e perguntei: tem certeza? E ele disse: "vai fazer uma ultra-sonografia amanhã. E eu vi...porque você vê, não vê nada, você vê um pontinho... eu vi aquilo e depois fui fazer um aborto... E aquilo me deixon muito mal, por dentro!! Eu falei que nunca mais ia fazer e evitei a minha vida inteira..."

D: "Daí, eu conheci um rapaz e engravidei dele...Na época, não havia condicões. Financeiramente era, assim, absolutamente impossivel manter aquela gravidez...E eu fiz. o aborto...né? E eu me senti muito mal com aquilo. Porque, no fundo, eu acho que eu queria ter... E foi tão forte assim que eu acho que a coisa...A gente ficou... Eu acho que esse aborto entrou, pesou muito no afastamento da gente...Mas isso não pesou para a escolha... para decidir o momento de S. Foram coisas bem diferentes...en já estava com a minha vida mais estabilizada, em termos financeiros eprincipalmente eu me sentia mais capaz como pessoa, eu estava, me sentia mais capaz como pessoa ... Mas pesou a questão da idade. Muito. Porque me deu um medo, assim, da vida estar me oferecendo uma oportunidade, e eu estar jogando aquela oportunidade fora. Eu tinha muita vontade de ter um filho, mas não foi programado para aquela hora, nem daquela maneira... Mas parecia assim que era uma coisa assim: "eu tive 
uma chance, eu estou tendo uma segunda chance, será que eu vou ter uma terceira chance?"

Diferentemente do desejo, a decisão de querer ter ou não o filho, não necessita passar pela decisão do parceiro, é individual. Este é o segundo aspecto a ressaltar e que aparece nos discursos das mulheres quando se referem ao fato de que resolveram ter o filho independentemente do parceiro. Entretanto, ao mesmo tempo em que afirmavam esta autonomia, contraditoriamente, sinalizavam, também, para a importância da participação do parceiro, inclusive na questão do ato de registrar, de dar um nome, que apenas para D. não foi possível. Mesmo quando, como no caso de K., o pai para o seu filho poderia ser qualquer um, seu parceiro registrou o filho, fato que ela considerou natural, já que era ele o pai natural!

F: “... meu projeto era ter o filbo, o pai ficou rolando, do jeito que, ele saiu de casa, entendeu? Então nós tínhamos relaçoes, às vezes nós tínhamos relações, porque tinha um vínculo... eu com meu companheiro, um vínculo sexual muito forte...Não bouve nenbum tipo de participação dele..."

$\mathrm{K}$ : "... e boje eu percebo até que não foi consciente, mas foi assim a única forma ou talvez a forma mais fácil e rápida de eu tê-lo sópara mim, porque era uma pessoa que não assumia nada, eu, desde o primeiro momento... eu engravidei na primeira transa... $\mathrm{Na}$ realidade, às vezes en olhava pra ele e dizia assim: $A$ ! $O$ que eu quero é o filho, entendeu? Mesmo porque era uma época mesmo de muitos problemas nos casamentos, todo mundo separando... E eu achava muito mais tranqüilo não ter, do que ter uma confusão depois. Dividir a criança, confundir a criança... porque, no fundo, era o filho que en queria... Eu não suporto e a sagrada família... Mas naquele momento a gente tinha que registrar, não tinha essa coisa de, era men filho e dele. Era nosso filho mesmo. Então ele foi lá e registrou... Tinha uma coisa do prazer em ter aquele filho, não conseguiu é manter nada, né? Se perdeu no meio do caminho... começou a disputar comigo"

T: "porque a gente era assim, um namoro... eu tô assim até hoje, eu gosto... se ele chegar hoje pra mim e falar: vamos? Eu vou! So não vou porque ele não fala mais... E ai a gente ficon meio assim... E eu, como estava menstruada, jamais poderia imaginar que alguma coisa além ia acontecer...Não, não pensava no pai, eu pensava em mim, na criança, é como se ele já fižesse parte, né? Por isso que en digo que a minha gravidez foi uma atitude muito egoísta... No mês seguinte, cadê a minha menstruação? Liguei para o men ginecologista e ele falou: Isso é uma raridade. Ai eu disse: então, eu tinha que ser uma raridade... Por isso en acho que foi coisa dos deuses..."

D: "Chegou uma hora que eu me aproximei dele e disse: Olha, eu entendo o teu problema e eu acho que você tem todo o direito de não querer ter um filho, do mesmo jeito que eu me reservo o direito de querer ter... Pra gente continuar do jeito que está eu prefiro continuar sozinha..."
Assim, as mulheres se colocavam diante de uma decisão que, como tal, não dependia do outro, como se elas se bastassem a si mesmas para aquela decisão. Ao afirmarem sua autonomia, atribuíram ao acaso, à sorte ou aos deuses a explicação sobre a gravidez que não esperavam. Porém, se, do ponto de vista da ideologia individualista, a decisão remete a cada um, independentemente do que pensa o outro, o desejo relança o sujeito na sua condição de incompletude, portanto, na contingência de ter que voltar-se para um outro que pode, quem sabe, completá-lo ... E, neste aspecto, todas sem exceção, reivindicavam, de uma forma mais explicita ou não, o nome do pai para os seus filhos!

Este é o dilema que surge nos discursos da maternidade de "produção independente". Biologicamente a mulher decide se quer ou não levar adiante a gravidez... Entretanto, como fazer um filho não é, para o sujeito humano, um ato meramente biológico, há todo um campo desejante de dois que se revela nos discursos. E, deste ponto de vista, há sempre um outro, parte deste ato:

T: "...Porque aí eu saberia qual a postura que ele tomou: "não, não quero ser pai, não vou reconbecer, tudo bem, ele morreria pra mim como pai, ia ser muito difícil eu matá-lo como homem, mas en acho que eu mataria ele como pai mesmo. Apesar de que eu acho que aí, provavelmente ele assim me matasse como mulher também... Porque foi um momento de muito amor, porque a minha relacão com o pai dela foi exatamente isso, momentos de amor, e ela representa a possibilidade de eu poder guardar isso..."

Na problemática da diferença sexual a mesma questão se coloca, ou seja, a dominância do discurso biológico na explicação da diferença. Entretanto, o que mais chama atenção é a imagem da maternidade como definidora da mulher. Em alguns depoimentos as mulheres chegam a dizer que a mulher só se completa quando se torna mãe. Embora tenham se aberto outros espaços de circulação para a mulher, a maternidade permanece como definidora de sua feminilidade.

$\mathrm{N}$ : “...até o momento que ela não tem, ela vai se sentir realizada em tudo, ela pode se sentir realizada em tudo, até ela não ter essa experiência. Porque é incógnita, ela não... não passou por isso. Agora, depois que ela tem filho, ela vai ter a certeza de que foi ai que se realizou mesmo..."

$\mathrm{Na}$ questão da conjugalidade ficou evidenciado, pelas entrevistadas, o que Sennett (1980) observou como marca desta subjetividade moderna. A não-socialização do amor físico, como uma tendência a defender-se do outro que pode ameaçar a liberdade de cada um, está na raiz do impasse vivido por cada uma das entrevistadas entre voltar-se para o relacionamento com o outro ou fecharse em si mesma para não ser aprisionada pelo outro. Como tendência, prevalece uma valorização da questão 
narcísica (Freud, 1914), onde a maximização do valor individualista não permite arriscar-se a possibilidades de frustração na relação com os demais. O esforço de racionalizar o sentimento com relação ao outro é transmitido em muitos momentos nos discursos. Como resultado deste acentuado olhar para si mesmo, que Sennett denomina mobilização narcísica, cultivar e defender a liberdade pessoal diante das experiências sociais e amorosas que funcionam, imaginariamente, como instrumentos de opressão, parece estar se tornando um modo de viver, pelo menos nesta subjetividade:

$\mathrm{N}$ : "Meu pai e minha mãe viveram bem cinqüenta anos, apaixonadíssimos. Quer dizer, eu fui casada com um cara que era apaixonado por mim...Eu me casei até pra satisfazer a eles, aos meus pais, porque não tinha necessidade alguma de eu me casar... eu não queria, achava que era besteira... Toda geração contesta a anterior, a minha geração foi aquela geração feminista... porque nada me assegurava que... eu tinha medo que, na medida em que "melasse" a relação da gente, ele se afastasse dela. Porque acontece, a única relacão duradoura é com filho, mesmo... É um casamento que você não separa, né? Ainda mais mãe..."

T: "O meu pai não tem nada de machista, primeiro que a mulher está sempre ao lado dele, namora a minha mãe até boje...E assim aconteceu, eu namorei ele, de vez em quando, a gente se namorava, quando a gente conseguia se ver, a gente se via. E foi a pessoa assim que eu só tive momentos bons, porque durante todo este relacionamento que a gente teve, esse, sei lá esse namoro, nunca foi cobrado nem de minha parte nem da parte dele nada, tipo onde você foi, porque você não veio... Nunca teve cobranca. Porque en tive relacionamentos fortes antes dele que me cobravam muito, e eu sempre detestei essa história de ser cobrada, até dai a minha necessidade da minha independência, da minha liberdade..."

T: "eu, às vezes, pensava: vou largar tudo e ir embora com P., mas aí pensava a minha história da minha liberdade, da submissão...Eu casaria, eu acho que eu casaria ... eu não sei se casaria porque chega num determinado ponto que a gente já se habitua tanto aos seus hábitos, às suas manias, eu acho que eu gostaria muito de continuar namorando ele, en gostaria muito do namoro, o casal, o dia-a-dia, aquela coisa, eu não... as pessoas dizem, de juntar as escovas de dentes, eu digo assim: a cueca na minha cama, não! A cueca todo dia na minha cama não! De casa, eu tive o exemplo fantástico do meu pai e da minha mãe que se namoram até hoje... E não é aquela coisa do hábito, de um aturar o outro, é a união mesmo, é o relacionamento, é um ajudando o outro... Meu avô e minha avó eles viveram juntos até morrer. Eu acho que o meu trauma é da cobrança, do dia-adia, daquela coisa de porque você fez isso... eu acho muito complicado o dia-a-dia, dividir a casa com um irmão, com um amigo é diferente, com um homem é mais complicado ainda..."

Psicologia: Reflexão e Crítica, 2002, 15(1), pp. 179-18

\section{Considerações Finais}

Tentando compreender de que forma o desejo de filho se articula nas circunstâncias da "produção independente", como, na época, se chamou esta experiência, pudemos concluir que esta escolha representou, para as mulheres, uma saída diante da imposição colocada pelo desejo de tornar-se mãe. Este desejo, recalcado através do discurso sobre a independência e a realização profissional, apareceu através da gravidez inesperada, da gravidez que aconteceu, da obra dos deuses, ou até mesmo, da última chance. Gravidez - surpresa que, finalmente, pôde ser bem-vinda e, por isto, preservada. Os discursos que afirmavam que a experiência de ser mãe traz um estado de completude para a mulher apareceram em todas as entrevistadas...

A situação de independência, como situação ideal, pretende fazer face à idéia de que a maternidade traz um estado de dependência da mulher diante do homem, e, portanto, é parte do imaginário constituído no interior do discurso feminista sobre a opressão masculina, como comentamos aqui. Então, parece que, para ser mãe, ser independente - seja lá o que isto signifique para cada uma das entrevistadas - é condição para levar a termo a gravidez, o que fica evidenciado nos comentários que todas, sem exceção, fizeram sobre o fato de já terem uma certa idade, ou seja: é agora ou nunca mais...

Gostaríamos ainda de chamar atenção para uma fala de uma das entrevistadas, quando comenta que caso o pai de sua filha não reconhecesse a criança,

"ele assim me matasse como mulher também... Porque foi um momento de muito amor, porque a minha relação com o pai dela foi exatamente isso, momentos de amor, e ela representa a possibilidade de eu poder guardar isso..."

Ela coloca no reconhecimento da filha pelo parceiro a confirmação de sua condição de mulher, pois o filho é a prova de que ali existiu um casal, um homem e uma mulher, momentos de amor... Reconhecer o filho é reconhecer que este momento existiu, o momento de encontro do diferente, do outro... Negá-lo seria negar a ela a legitimação do lugar de mulher.

A "produção independente" parece significar uma tentativa de construir um novo lugar de indivíduo para a mulher. Este novo lugar, em processo de construção, se reconhece, entretanto, na mais antiga marca cultural da mulher nas sociedades, a maternidade.

Finalmente, gostaríamos de fazer uma observação a respeito do que mais acima mencionamos sobre esta experiência de maternidade como uma ante-sala das novas tecnologias de reprodução. Não sendo o objeto de discussão do presente artigo, é inevitável que pensemos se podemos 
retirar do discurso da "produção independente" alguns elementos que anunciam, de certa forma, o imaginário que legitima as novas tecnologias de reprodução. Acreditamos que sim. Queremos nos referir precisamente à autonomização da sexualidade em relação à reprodução que observamos ter se dado a partir do advento dos contraceptivos e da maximização dos valores individualistas nas sociedades modernas.

Presente na experiência da "produção independente" a autonomização entre sexualidade e reprodução permitiu, como analisamos, que a problemática da procriação fosse reduzida aos termos da reprodução biológica, termos em que vem sendo tratada. Com o alento e a esperança que a ciência oferece ao sonho humano de superar situações anteriores que impossibilitavam a procriação, constituiu-se a demanda de filhos possíveis no universo destas novas tecnologias.

Entretanto, isto se faz ao preço de negar as dimensões simbólicas inerentes à procriação, como também comentamos aqui, ao apresentar os argumentos das entrevistadas sobre a crença na experiência de maternidade como uma escolha, como uma opção. No momento da "produção independente", a ênfase biológica, devido ao imaginário libertário daqueles anos, era na contracepção. Julgamos, porém, que este mesmo imaginário, veio legitimar os modos de pensar das novas tecnologias de reprodução.

Não assumimos aqui nenhuma postura crítica saudosista ou mesmo obscurantista que poderia nos levar ao absurdo de lamentar as descobertas da ciência! Apenas consideramos que, assim como a "produção independente", as novas tecnologias de reprodução demandam urgentemente, uma discussão no campo da ética, que considere, sobretudo, as conseqüências para os sistemas de filiação e para o lugar da ancestralidade.

\section{Referências}

Beauvoir, S. (1980). O segundo sexo ( S. Milliet, Trad.). São Paulo: Difusão Européia do Livro. (Original publicado em 1949)

Birman, J. (1997). Estilo e modernidade em psicanálise. São Paulo: Editora 34. Bourdieu, P. (1990). La domination masculine. Actes de la recherche en sciences sociales (Vol. 84, pp. 4-31). Paris: Minuit.

Duarte, L. F. (1995). Horizontes do indivíduo e da ética no crepúsculo da família. Em A. C. Ribeiro \& C. Ribeiro (Orgs.), Família em processos contemporâneos: Inovaáōes culturais na sociedade brasileira. São Paulo: Loyola.

Dumont, L. (1993). O individualismo: Uma perspectiva antropológica da ideologia moderna (Alvaro Cabral, Trad.). Rio de Janeiro: Rocco. (Original publicado em 1983)

Ehrenberg, A. (1998). La fatigue d' être soi. Paris, Ed. Odile Jacob.

Héritier. F. (1996). Masculin/féminin, la pensée de la difference. Paris: Odile Jacob.

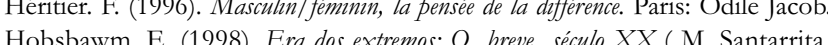

Tsbawm, E. (1998). Era dos extremos. O breve seculo XX (M. Santarrita,

Trad) $\mathrm{S}$. Palo: Companha das Letras. (Orignal publicado em 1994)

dução (T.Oliveira Brito, P.H. Britto \& C. Monteiro Oiticica, Trads.). Em J. Salomão (Org.), Edicão standard brasileira de obras completas de Sigmund Freud (Vol. 14, pp. 89125). Rio de Janeiro: Imago. (Original publicado em 1914)

Freud, S. (1969). O mal-estar na civilização (J. O. Aguiar Abreu, Trad.). Em J. Salomão (Org.), Edição standard brasileira de obras completas de Sigmund Frend (Vol. 21, pp. 75- 171). Rio de Janeiro: Imago. (Original publicado em 1930)

Laqueur, T. (1987). Orgasm, generation, and the politics of reprodutive biology. Em T. Laqueur \& C. Gallagher (Orgs.), The making of modern body (pp.1-43). Berkeley: University of California Press.

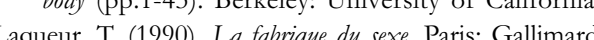

Rubin, G. (1975). The traffic in women: Notes on the "political economy of sex". Em R. Reiter (Org.), Towards an anthropology of women (pp. 157210). New York: Monthly Review Press.

Salém, T. (1985). A trajetória do «casal grávido»: De sua constituição à revisão de seu projeto. Em S. Figueira (Org.), Cultura da psicanálise (pp. 35-61). Rio de Janeiro: Editora Brasiliense.

Schwarzer, A . (1985). Simone de Beauvoir hoje. Rio de Janeiro: Rocco.

Sennett, R. (1980). Narcisismo y cultura moderna (Jorge Fibla, Trad.). Barcelona: Kairós.(Original publicado em 1977)

Tort, M. ( 1995). Désir d'enfant ou offre d'enfant? Em Cabiers de l'école des sciences philosophiques et religieuses (Vol. 17, pp. 59-69). Paris: CESPR.

Velho, G. (1988). Destino e projeto: Uma visão antropológica. Em A. C. Ribeiro (Org.), O destino (pp. 79-81). Rio de Janeiro: Terceira Margem.

Recebido:26/04/2001 Revisado: 06/09/2001 Aceito: 24/09/2001

Sobre as autoras

Ana Maria Szapiro é Psicóloga, Mestre em Psicologia Clínica pela PUC-Rio, e Doutora em Psicologia pela PUC-Rio. Professora Adjunta do Departamento de Psicologia Social do Instituto de Psicologia da Universidade Federal do Rio de Janeiro, é Coordenadora do Projeto "Clínica Social da AIDS”, desenvolvendo atualmente pesquisa sobre representação social da epidemia em mulheres. Terezinha Féres-Carneiro é Psicóloga, com Mestrado em Psicologia Clínica pela PUC-RJ, Doutorado em Psicologia Clínica pela PUC-SP e Pós-Doutorado em Psicoterapia de Família e Casal pela Universidade de Paria V. Professor Titular do Departamento de Psicologia da PUC-Rio, é Bolsista de Produtividade do CNPq, coordenando o grupo de Pesquisa Casal e família: Processos Psicossociais e Psicoterapia. 